\title{
Audit Quality: The Role of Board Structure in Family Firms
}

\author{
Mervi Niskanen* \\ Jukka Karjalainen** \\ Tensie Steijvers*** \\ *Professor, University of Eastern Finland \\ **Ph.D. candidate, University of Eastern Finland \\ ***Professor, Hasselt University, Belgium
}

June 13, 2011

\begin{abstract}
This study investigates the role that board structure has on the demand for audit quality in connection with family ownership in a sample of private firms. In addition to this, we also shed light on whether ownership structure and board structure are substitute mechanisms in resolving agency costs in private family firms. Our main results show that the presence of outsiders on the board increases the demand for audit quality in the overall sample as well as in the presence of family ownership. Our results also confirm previous results and indicate that family firms are less likely to engage a Big 4 auditor even when we control for board structure. Additionally, we find that in a subsample of family firms the probability of choosing a Big 4 auditor decreases with an increase in CEO ownership and is higher in firms with outside boards. When we investigate the interaction between CEO ownership and outside boards, we find that role of outside boards is weaker when CEO ownership increases.
\end{abstract}

Keywords: Board Structure, Audit Quality, Private firms

Corresponding author's address: Mervi Niskanen, Department of Business, University of Eastern Finland, PO Box 1627, FIN-70211 Kuopio, Finland.

E-mail: Mervi.Niskanen@uef.fi 


\section{Audit Quality: The Role of Board Structure in Family Firms}

\section{Introduction}

The aim of this study is to investigate the role that board structure has on the demand for audit quality in connection with family ownership in a sample of private firms. The approach to audit quality adopted in this study is based on a notion that there are differences in audit quality and that these differences can be inferred by comparing different groups of auditors. The bulk of this research concentrates on the dichotomy between large and small audit firms as the basis for differential audit quality. This line of research is based on DeAngelo (1981), who argues that accounting firm size can be used as a proxy for audit quality because no single client is important to the large firm and the auditor has a greater reputation to lose if they misreport.

The role that inside equity ownership in general and family ownership in particular has on the demand for audit quality in private firms has been given some attention in the literature. The role that board structure as an alternative or complimentary mechanism has in this context has, however, been mostly neglected. Lennox (2005) finds that managerial ownership is related to the demand for Big 4 audits in private firms but not in public firms. Carey, Simnett, and Tanewski (2000) suggest that the demand for voluntary audits increases when agency costs increase. Niskanen, Karjalainen and Niskanen (2010) find that the demand for audit quality is lower in family firms as opposed to other types of private firms. Their results further indicate that an increase in managerial ownership in a sample of family firms decreases the demand for audit quality.

Prevost's et al. (2002) suggests that board composition and inside equity ownership are substitute mechanisms in controlling agency problems. The role that outside boards have on the demand for audit quality is, however, not that clear. One line of thought suggests that firms with outside boards are less likely to demand higher quality audits, because the outside board members by definition serve to reduce agency costs, thus making it unnecessary to seek further monitoring. Alternatively, it can be argued that the board may seek to protect its own reputation, to avoid legal liability (see, e.g., Gilson, 1990) or to promote shareholder 
interests by purchasing higher audit quality. To our knowledge, there is no previous research on the role that board structure has on the demand for audit quality in private family firms.

This study extends the findings of previous studies in two important ways. First, we extend the analysis on the role of the choice of auditor in private family firms to include the role that board structure plays in this selection. Furthermore, we are able to provide new information on the interaction between ownership and board structure in this context. Our results show that the presence of outsiders on the board increases the demand for audit quality. The results also confirm previous results and indicate that an increase in family ownership decreases the likelihood that the firm will engage a Big 4 auditor even when we control for board structure. We also find that in a subsample of family firms the probability of choosing a Big 4 auditor decreases with an increase in CEO ownership and is higher in firms with outside boards. When we investigate the interaction between CEO ownership and outside boards, we find that the role of outside boards is weaker when CEO ownership increases. And, additionally, the negative impact of CEO ownership is stronger in the firms with outsiders on the board.

Section two of the study discusses the relevant literature. Section three presents the data and motivates the use of variables applied in the analysis. Section four presents descriptive statistics on the variables. Section five presents the empirical tests explaining the associations between firm characteristics and the use of a Big 4 auditor or a certified auditor. Section six concludes the study.

\section{Literature Review and Hypothesis Development}

Agency theory considers auditing as one of the main monitoring or bonding devices dedicated to preventing and regulating agency costs. Auditing leads to a reduction of information asymmetries on accounting numbers, which increases the reliability of accounting profits and resulting dividends. It minimizes residual loss resulting from managers' opportunism in financial reporting. Moreover, external auditors also verify the existence of appropriate internal control mechanisms. Efficient internal control systems would also reduce the agency costs. This monitoring makes it more difficult for managers to conceal the consequences of their actions from the other stakeholders. In addition, auditing 
can also strengthen the reputation of family firms. The undiversified portfolio of private family firm owners implies a long term view of the owners and greater reputation concerns. Therefore, the role of the auditor to lend credibility to their disclosures can be very important for family firms (Ang, 1992; Fortin, 2007).

Piot (2005) and Burgstahler et al. (2006) argue that a firm would be more likely to appoint a high quality auditor if the firm copes with more agency problems. The appointment of a high profile auditor has to result in making the published accounts more credible, increasing the reliability of the firm's operations and management and reduce agency costs (Piot, 2005). Following extant research, large audit firms are postulated to have more incentive to produce high quality audits (Francis, 2004). This high quality is necessary to produce beneficial effects as a monitoring device. A decision to reduce quality to retain a client would lead to a higher loss for its whole portfolio compared to the retention benefits (De Angelo 1981). Auditor specific brand name investments have to be preserved. Craswell et al. (1995) find that large audit firms earn significantly higher audit fees and they attribute part of this premium to higher investments in expertise.

Many empirical studies have investigated the role of audit and audit quality in general. However, the results are by no means straightforward. Most studies focussing on the interaction between agency costs and auditor choice investigate large listed firms. Ball and Shivakumar (2005) and Beatty et al. (2002) point out that these results cannot be extended to private firms. Lennox (2005) suggests that the monitoring value of auditing may be higher in private firms because they are less vulnerable to takeover and are required to disclose much less accounting information to shareholders. Moreover, stock prices of listed firms provide information to shareholders, helping them to monitor manager's actions. If the literature on the role of auditing in private firms is scarce, it is virtually nonexistent for private family firms. Though the agency literature is suggestive of potential conflict in family businesses (Fama and Jensen, 1983), empirical research investigating the monitoring response is limited. To our knowledge, the studies by Carey et al. (2000) and Niskanen et al. (2009) are the only studies investigating the role of the auditor in private family firms. Their results suggest that higher agency costs increase the demand for voluntary or higher quality audits. 
Traditional agency theory predicts that in private family firms, the shareholder-manager agency conflict is expected to be minimal. Concentrated ownership and owner-management would lead to a minimum or even zero level of agency costs between owners and managers (Jensen and Meckling, 1976; Fama and Jensen, 1983). Some studies by, e.g., Chrisman, Chua, and Litz (2004) suggest that agency problems are less severe in family firms than in non-family firms. The reasoning behind this argument is that family firms focus more on the firm's long-term survival, wishing to pass the firm onto their heirs, and good reputation, which is likely to promote trust in other stakeholders (James, 1999; Sirmon and Hitt, 2003). Moreover, the large undiversified equity position and control of management and directors places the family in an excellent position to influence and monitor the firm (Fama and Jensen, 1983). In addition, kinship and parental altruism are expected to temper self-interest of family agents (Schulze et al., 2003). However, there is now a debate going on whether private family firms incur higher or lower agency costs (e.g. Schulze et al., 2001; Schulze et al., 2003). These recent studies contest the traditional agency view and argue that agency costs in private family firms could be even higher than in non-family firms due to possible negative effects of self-control and parental altruism. So, parental altruism and family ownership may have a drawback or dark side (Schulze et al., 2003). Controlling owners may be more vulnerable for self-control problems, increasing the probability of risk shifting behaviour and hold up (Lubatkin et al., 2005). For example, once a family has enough ownership for unchallenged control, it can begin to abuse its power by taking resources out of the business (Claessens et al., 2002). Moreover, parents' altruism may lead them to be generous to their children even when these children free ride and lack the competences to lead the firm. In addition, family controlled firms have a higher likelihood to be characterized by special dividend payouts or excessive compensation (Anderson and Reeb, 2003). Therefore, family firms may be reluctant to allow monitoring of their behavior and thus may be less eager to hire a high quality auditor in order to preserve their perquisites. So even though private family firms may cope with higher agency costs, they may be reluctant to allow a high quality auditor. Thus, we argue:

Hypothesis 1 : Private family firms are less likely to demand a high quality auditor

However, there is a growing consensus that family firms cannot be viewed as a homogeneous entity (e.g. Chrisman et al., 2005, Villalonga and Amit, 2006, Westhead and Howorth, 2007). 
Thus, it would be rash to conclude that $\underline{\text { all }}$ private family firms would be hesitant to hire a high quality auditor. Studying the effect of agency costs on auditing, Carey et al. (2000) only consider the effect of non-family management and non-family shareholders in private family firms that affect, through their impact on agency costs, the appointment of a high/low quality auditor. This leaves us with a wide array of other typical family firm characteristics that may influence the agency costs and the resulting choice of auditor. Therefore, we study CEO ownership share which may play an important role in determining the level of agency costs prevailing in the firm.

A lower CEO ownership share is mainly orginated in an evolution of the firm throughout generations. Many prior studies (e.g Westhead et al., 2002; Schulze et al., 2003a; Sonfield and Lussier, 2004; Jaffe and Lane, 2004; Kellermanns and Eddleston, 2006; Bammens et al., 2008) argue that several family attributes may change throughout time as the ownership structure changes. If descendants join the firm, this will increase the potential for conflicts of interest concerning business issues, diverging views and information asymmetries between owners and manager. The family starts to lose cohesiveness, has different personal goals, values, commitment to the business (Lambrecht and Lievens, 2008) and copes with a lessened intensity of family ties which will engender shareholder-manager agency costs. Due to the changing nature of altruism, the descendant will put the welfare of the own nuclear household before the welfare of the extended family (Schulze et al., 2003a; Lubatkin et al., 2005). They may also enjoy excessive salaries and perks, they may shirk, or make risk avoidant decisions in their own interest (Hanlon et al., 2004). Therefore, it could be argued that if the CEO owns a lower fraction of shares, there will be a higher need for audit quality. Given the private benefits the CEO obtains from the firm, he will not be inclined to demand for high audit quality. However, other shareholders, together possessing a significant amount of the shares, being aware of these high agency costs, may urge for the appointment of a high quality auditor to mitigate these agency costs.

In case of a high CEO ownership stake, the CEO bears many of the costs and receives nearly all of the benefits of any of his actions. A CEO with a high ownership share is mainly worried by the preservation of the good reputation and passing the firm to his children. They may be less eager to engage in rent extraction because this may harm the firm. Parental altruism gives the controlling owner/CEO incentive to take actions that they believe would 
benefit the nuclear family. They tend to focus on family goals at the expense of other financial goals (Westhead, 2003). In addition, the emotional attachment to the firm, the self identification with the firm and the utility derived from the ability to exercise authority are strong (Gomez-Mejia et al., 2007; Schulze et al., 2003). Therefore, shareholder-manager agency costs decrease as well as the need to hire a high quality auditor. Thus, we hypothesize:

Hypothesis 2: A decrease in CEO ownership in family firms will increase the demand for high audit quality.

In private family firms, boards of directors may perform several board roles (Voordeckers et al., 2007). Besides providing advice, counselling and networking, they serve to align the interests of managers with shareholders interests so as to safeguard shareholders' interests (Johannisson and Huse, 2000). The board of directors is responsible for monitoring and evaluating senior management. Within an effective corporate governance structure, the board of directors must verify whether the firm's management acts in the best interest of the family and/or nonfamily shareholders. Outside board members are believed to be independent from management and they are expected to provide superior performance benefits to the firm (Fama 1980; Dalton, Daily, and Ellstrand 1998). The governance literature generally suggests that as boards become increasingly independent of management, their monitoring effectiveness increases, thereby decreasing managerial opportunism (Harford et al., 2008). Independent board of directors can be considered as a power-balancing mechanism to resolve agency conflicts: they have an important control role to monitor management to ensure they do not expropriate stakeholders' interests. They act to prevent the misappropriation of firm's resources and to mitigate opportunistic behaviour. Outside board members are expected to possess the necessary expertise and commitment to monitor managers' behaviour (Minichilli et al., 2009). In order to perform this monitoring task effectively, the directors should have the necessary expertise and objectivity that ostensibly mitigate the agency costs. Previous literature suggests that an effective board should be comprised of outside directors (Zahra and Pearce 1989; Dalton et al. 1998). As outside board members are considered as effective monitors in reducing agency costs, the need for high audit quality as an agency cost reducing mechanism decreases. 
However, even though audit quality and outside board representation can be both considered as monitoring tools, they could act as complementary tools. Fama (1980), Fama and Jensen (1983) and Gilson (1990) suggest that the board may seek to protect its own reputation or to avoid legal liability (see, e.g., Gilson ,1990). Alternatively, their motivation may lie in an attempt to promote shareholder interests by purchasing higher audit quality. There is, however little empirical evidence on the relationship between board independence and the demand for audit quality. Carcello et al. (2002) investigate the association between board independence and audit fees with a sample of large public companies. Their results indicate that there is a positive association between board independence and audit fees, suggesting that outside board members seek to protect their reputation and to avoid legal liability by demanding higher audit quality. Beasley et al. (1998) investigate the role that outside board members play in the choice of a brand name auditor in a sample of insurance companies. They find that the likelihood that the firm employs a brand name auditor increases with an increase in the percentage of outside board members. Therefore, we argue:

Hypothesis 3: Outside board representation will increase the demand for audit quality.

Based on the above argumentation, management can reduce the monitoring role of the board by implementing CEO duality. CEO duality refers to a board leadership structure in which the same person undertakes both of the roles of chief executive officer and chairman of the board (Bozec 2005). As the CEO significantly influences the membership of corporate boards, CEO duality is widespread. Proponents of agency theory argue that different individuals should hold the positions of CEO and chairman. Jensen (1993) suggests that boards are less effective monitors when the CEO doubles as the chairman of the board. Top management's influence over the board composition seems contrary to effective corporate governance. Gubitta and Gianecchini (2002) claim that, from an agency perspective, disproportionate concentration of power in the hands of a single person could favour opportunistic behaviour. Splitting the roles of CEO and chairman weakens the power of the $\mathrm{CEO}$ and reduces the potential for management to dominate the board. 
Hypothesis 4: CEO duality coincides with lower demand for audit quality.

As CEO ownership share is argued to negatively affect the use of high audit quality, we posit that CEO ownership share will also affect the relationship between the outside board representation and audit quality. As argued in hypothesis 3, outside board representation will increase the demand for audit quality. However, as argued in hypothesis 2, if CEO ownership is high, the shareholder-manager agency costs decrease, reducing the need to hire a high quality auditor. Therefore, the positive relationship between outside board representation and audit quality will be weakened if the CEO ownership share is high and thus agency costs are low according to traditional agency theory.

Hypothesis 5: The positive relationship between outside board representation and audit quality will be weakened if CEO ownership share is high

\section{Data}

\section{Sample}

The data used in this study consist of ownership, financial, and auditing data of Finnish private firms for fiscal years 2000 to 2006 . The data on family ownership, board structure and control variables are collected through a private survey directed to 1500 randomly selected Finnish private companies. The companies were selected from a commercial VOITTO database of Asiakastieto Ltd, a Finnish financial and credit information company. The financial and auditing data were collected from the same database and combined with survey data. In this database, firm-specific financial and auditing data are available for periods of different length ranging from one to five years. As a result, our database is in the form of an unbalanced panel containing firm-specific data from one to five fiscal years from 2000 to 2006. The final sample containing data on all variables needed in the regression analysis consists of 441 individual firms and 1,637 observations.

\section{The Finnish Context}


The Finnish environment provides an interesting setting for investigating auditing in small and medium sized firms. One of the reasons behind this argument is that in Finland virtually all businesses regardless of size are required to report public financial statements that are subject to full financial statement audit (Knechel, Niemi, \& Sundgren, 2008).

Our database also enables us to investigate the choice between three different types of auditors: Big 4, (non-Big 4) certified and non-certified auditors. Finland has a two-tier system of auditor professional qualifications. The lower level qualified auditors are called HTM auditors (auditors and audit firms authorized by a local Chamber of Commerce) and higher level qualified auditors KHT auditors (auditors and audit firms authorized by the Central Chamber of Commerce). Also, during the sample period (2000-2006) all Finnish firms were required to have a financial audit regardless of firm size. The firms were obligated to appoint a certified auditor if a legally determined size-threshold was exceeded in the fiscal year. This applied, if at least two of the following three criteria were exceeded: (1) book value of assets exceeds 340000 euros, (2) turnover exceeds 680000 euros, or (3) the firm had over 10 employees on average. If this size-threshold was not exceeded, the firms could choose an auditor without any professional certification as long as this auditor possessed sufficient knowledge and experience in financial auditing (Sundgren, 1998).

\section{Research design}

\section{Dependent variables}

Table 1 describes the variables used in the empirical analyses of this study. As the dependent variables in the main logistic regression analysis we apply a dichotomous indicator of firm's auditor choice. Our first dependent variable BIG_4 indicates firms employing an auditor that represents one of the international Big 4 audit firms (i.e., PricewaterhouseCoopers, Deloitte Touche Tohmatsu, Ernst \& Young, and KPMG). Because of their large clienteles and established international reputations, the Big 4 audit firms are expected to lose less (more) as a result of maintaining (losing) their independence in comparison to smaller audit firms (DeAngelo, 1981; Cano-Rodríquez, 2010). The validity of the Big 4 vs. non-Big 4 dichotomy as a proxy for audit quality is also supported by previous empirical findings (e.g., Becker et 
al., 1998; Francis et al., 1999; Van Tendeloo \& Vanstraelen, 2008; Cano-Rodríquez, 2010). Our Finnish dataset allows us to identify different groups of auditor. As the second dependent variable, we define KHT which indicates firms that employ KHT qualified auditors. The sample firms are small enough not to be required to engage KHT auditors and, therefore, an appointment of a KHT auditor is voluntary for these firms. Our third dependent variable CERTIFIED indicates firms that employ a certified HTM or KHT auditor. In the subsample of smaller firms allowed to use non-certified auditors, an appointment of a certified auditor is expected to indicate the demand for higher audit quality. We expect these variables to indicate firm's demand for differential audit quality.

\section{TABLE 1}

In the multinomial logit analysis we apply the dependent variable AUDITOR, which is defined as having the value of 1 for firms employing non-certified or a HTM auditors, the value of 2 for firms employing non-Big 4 KHT auditors, and the value of 3 for firms employing Big 4 KHT auditors.

\section{Board and ownership variables}

We employ two dichotomous variables as measures of board effectiveness in our analysis. The first variable CEO_DUAL indicates firms with CEO duality, that is, the Chief Executive Officer of the firm is also serving as a Chairman of the Board. The second variable OUTSIDE_BM indicates firms with at least one outside board member (i.e., other than family member, director, other personnel, or investor). In unreported analysis we employ one further measure of board structure, i.e., NONFAM_BM indicates firms with at least one nonfamily board member. As a measure for board size we include B_SIZE, defined as a natural logarithm of one plus the number of board members. Our ownership variables include CEO_OS, defined as a percentage share of CEO's ownership, and FAMILY, indicating family held firms (family ownership > 50\%).

\section{Control variables}


To control for the potential demand for audit quality arising from debt contracting we include the variable LEVERAGE defined as a ratio of total debt to total assets (Watts \& Zimmerman, 1986). Following previous studies, we include a set of control variables for different aspects of audit complexity, which can have an impact on firm's demand for audit quality. To control for organizational complexity we define the variable SIZE as a natural logarithm of total assets, and the variable GROUP, indicating whether the firm belongs to a corporate group (i.e., the firm is a parent company, a subsidiary or a jointly controlled company) (Knechel et al., 2008). To control for the transactions complexity, we define the variable A_TURN as a ratio of sales to total assets, and the variable EXPORT, indicating whether the firm has foreign sales (Chaney et al., 2004). Finally, to control for the audit effort required for verifying firm's risky assets, we define the variable INV_REC as a ratio of inventory plus receivables to total assets (Healy, 1985).

To control for the firm's default risk which can have an impact on the demand for audit quality we include AGE, defined as a natural logarithm of one plus years since firm's incorporation; ROA, defined as a ratio of earnings before interest and taxes to total assets; QUICK, defined as a ratio of current assets minus inventory to current liabilities; and DISTRESS, indicating whether the firm's book value of equity is negative (Mansi et al., 2004; Fortin \& Pittman, 2007). To control for legal requirements we define the variable LAW, indicating whether the firm is based on its size legally required to appoint a certified HTM or KHT auditor (i.e., when at least two of the following criteria is met: employees $>10$, turnover > 680 TEUR, and total assets > 340 TEUR). Finally, we include controls for the fiscal year.

\section{Descriptive statistics}

Table 2 presents descriptive statistics for the variables. With respect to the board variables, the reported statistics show that of the sample firms $48.75 \%$ have CEO duality, $77.34 \%$ have non-family board members, and $15.39 \%$ have outside board members according to our definition. Board size is on average 2.4 board members ranging from 0 to 12 members. The average share of CEO ownership is $46.80 \%$ whereas $54.49 \%$ of the sample firms are family held. Statistics also show that $13.44 \%$ of the sample firms employ a Big 4 audit firms, 
$31.52 \%$ employ KHT auditors, and $77.95 \%$ employ certified HTM or KHT auditors. The sample firms have total assets of 309 TEUR on average.

\section{TABLE 2}

Table 3 presents univariate Pearson (Spearman) correlations below (above) the diagonal. For brevity, we outline only the Pearson correlations. The variable CEO_DUAL is negatively correlated with the dependent variables BIG_4, KHT, and CERTIFIED. The variable NONFAM_BM is positively correlated with KHT, whereas the variable OUTSIDE_BM is positively correlated BIG4 and KHT. The variable CEO_OS is negatively correlated with BIG_4, KHT, and CERTIFIED, whereas FAMILY is negatively correlated with BIG_4. Between the explanatory and control variables, we observe the largest correlations between the variables LAW and SIZE (0.735), CEO_DUAL and CEO_OS (0.385), as well as between CEO_DUAL and B_SIZE (0.378). Overall, the correlations do not indicate a problem of multicollinearity.

\section{TABLE 3}

\section{Results}

Table 4 presents pooled (cross-sectional time-series) logistic regressions for the likelihood that the private firm employs a Big 4 audit firm using the overall sample. These regressions control for family ownership (FAMILY) and allow the effect of board effectiveness on the auditor choice to differ between family firms and nonfamily firms. Regressions in columns (1) and (2) use CEO_DUAL and OUTSIDE_BM as measures for board effectiveness, respectively. The results in column (2) of Table 4 show that the presence of outside board members (OUTSIDE_BM) increases the likelihood that the private firm will employ a Big 4 audit firm. This result confirms hypothesis 3, suggesting that either the board seeks to protect its own reputation, to avoid legal liability or to promote shareholder interests by purchasing higher audit quality. However, CEO duality (CEO_DUAL) does not appear to have an impact on the likelihood to choose a Big 4 audit firm in our sample of private firms. In addition, the results in columns (1) and (2) indicate that the likelihood to appoint a employ a Big 4 audit firm is lower in private family firms as opposed to nonfamily firms (FAMILY), which is well 
in line with hypothesis one and previous studies indicating that the demand for audit quality is lower in family firms. Based on the insignificant coefficients of the interaction terms, this ownership effect appears to be insensitive to the board structure in place.

\section{TABLE 4}

Table 5 presents the regressions for the subsample of private family firms (FAMILY $=1$ ) in columns (1) and (2), and for larger private family firms (FAMILY = 1, LAW $=1$ ) in columns (3) and (4). These regressions control for CEO ownership (CEO_OS) instead of family ownership. The results in columns (2) and (4) confirm the results obtained for the overall sample by showing that board effectiveness in terms of the presence of outside board members (OUTSIDE_BM) increases the likelihood that the private family firm will employ a Big 4 auditor, giving further support for hypothesis 3 . In addition, the results suggest that the effect of CEO ownership (CEO_OS) on the Big 4 auditor choice is negative, as suggested in hypothesis 2 . The results for the subsample of family firms also indicate that the effect that the outside board members have on the demand for audit quality decreases as CEO ownership decreases. This supports hypothesis 5 . The results also imply that the negative association between CEO ownership and the likelihood to appoint a Big 4 auditor is stronger for private family firms with outside board members (CEO_OS x OUTSIDE_BM). Furthermore, this pattern of results appears to be even more pronounced for larger private family firms. Combined, the results seem to suggest that CEO ownership is a more powerful determinant of the demand for audit quality than an outside board, even if the latter has some impact.

\section{TABLE 5}

As an attempt to take into account the Finnish auditing environment with the different types of auditors, we also run the regressions of Tables 4 and 5 by using KHT as the dependent variable instead of BIG_4 and CERTIFIED as the dependent variable for smaller private firms that are allowed to use non-certified auditors using (not reported). In the models with CERTIFIED as the dependent variable, none of the board variables were significant. In the models with KHT as the dependent variable, in the overall sample of private firms, CEO duality is inversely related (at the $10 \%$ level) to the likelihood to employ a KHT auditor. Furthermore, in the subsample of private family firms, CEO ownership is inversely related (at 
the $10 \%$ level) to the likelihood to employ a KHT auditor only when CEO is also the Chairman of the Board

To investigate the different types of auditors in relation to each other, we re-estimate the regressions in Table 5 by using multinomial logit analysis. These results are presented in Tables 6 and 7. These regressions use AUDITOR as the dependent variable by treating firms employing non-certified and HTM auditors as the comparison group of observations. In our sample of private firms, the choice of a non-Big 4 KHT or a Big 4 auditor is expected to represent voluntary choice of a higher quality auditor and, therefore, demand for audit quality. The regressions in columns (1) to (2) and (3) to (4) use CEO_DUAL and OUTSIDE_BM as a measure for board effectiveness, respectively.

\section{TABLE 6}

The results in column (4) of Table 6 and 7 confirm the main results by showing that for private family firms the presence of outside board members (OUTSIDE_BM) increases the likelihood to employ a Big 4 auditor in comparison to non-certified and HTM auditors. The nonsignificant results for non Big 4 KHT auditor imply that this auditor type does not seem to have the similar status as the Big 4 audit firms in the eyes of outside board members. The results in column (1) of Table 6 also show that for private family firms CEO ownership appears to be inversely related to the likelihood to employ a non-Big 4 KHT auditor if the CEO is also the Chairman of the board (CEO_OS x CEO_DUAL). In addition, the results in column (4) of Table 7 show that for larger family firms CEO ownership (CEO_OS) is inversely related to the likelihood to employ a Big 4 audit firm and that this association is stronger for family firms with outside board members (CEO_OS x OUTSIDE_BM). However, the results in columns (1) and (2) of Table 7 show no evidence that CEO duality has an impact on the auditor choice for larger family firms.

\section{TABLE 7}

We also ran multinomial logit regressions using NONFAM_BM as a measure for board effectiveness. These untabulated regressions suggest that board effectiveness in terms of nonfamily-board members increase the likelihood to employ a non-Big 4 KHT auditor in 
comparison to non-certified and HTM auditors in the overall sample of private firms and in the subsample of larger private family firms.

With respect to the control variables, the results in Tables 6 and 7 reveal the following. In the overall sample of private firms (Table 6), the demand for higher quality auditors in terms of non-Big $4 \mathrm{KHT}$ and Big $4 \mathrm{KHT}$ auditor is positively related to private firm size, and negatively related to profitability. In addition, financial distress and organizational complexity in terms of group membership appears to increase the likelihood to choose a nonBig 4 KHT auditor. In the subsample of private family firms (Table 6), the demand for higher quality audits appears to be similarly driven by firm size and financial distress. For larger

private family firms (Table 7), however, the effect of financial distress appears to be reversed. For these firms, the demand for Big 4 audits appears to increase with reduced default risk as a result of improved liquidity (QUICK).

\section{Conclusion}

The aim of this study is to investigate the role that board structure has on the demand for audit quality in connection with family ownership. The approach to audit quality adopted in this study is based on a notion that there are differences in audit quality and that these differences can be inferred by comparing different groups of auditors. The role that inside equity ownership in general and family ownership in particular has on the demand for audit quality in private firms has been given some attention in the literature. The role that board structure as an alternative or complimentary mechanism has in this context has, however, been mostly neglected. One line of thought suggests that firms with outside boards are less likely to demand higher quality audits, because the outside board members by definition serve to reduce agency costs, thus making it unnecessary to seek further monitoring. Alternatively, it can be argued that the board may seek to protect its own reputation, to avoid legal liability or to promote shareholder interests by purchasing higher audit quality.

This study extends the findings of previous studies in two important ways. First, we extend the analysis on the role of the choice of auditor in private family firms to include the role that board structure plays in this selection. Furthermore, we are able to provide new information 
on the interaction between ownership and board structure in this context. Our results confirm previous results and indicate that an increase in family ownership decreases the likelihood that the firm will engage a Big 4 auditor even when we control for board structure. Our results also show that the presence of outsiders on the board increases the demand for audit quality. We also find that in a subsample of family firms the probability of choosing a Big 4 auditor decreases with an increase in CEO ownership and is higher in firms with outside boards. When we investigate the interaction between CEO ownership and outside boards, we find that role of outside boards is weaker when CEO ownership increases. Our results imply that outside board members require higher audit quality and that CEO ownership is important in determining how important this demand is. When it comes to the different types of auditors that Finnish environment allows us to examine, the results suggest that Big 4 audit firms seem to be valued higher that the Finnish non Big 4 KHT auditors. This implies that the quality or the credibility of a Big 4 audit firm is higher than that of other certified auditors. 


\section{References}

Anderson, R.., Mansi, S. \& Reeb, D. (2003). Founding family ownership and the agency cost of debt. Journal of Financial Economics, 68, 263-285.

Ang, J.S. (1992). On the theory of finance for privately held firms. Journal of Small Business Finance, 1(3), 185-203.

Ball, R. and Shivakumar, L., 2005, Earnings quality in UK private firms: comparative loss recognition timeliness, Journal of Accounting and Economics 39(1), 83-128.

Bammens, Y., W. Voordeckers, and A. Van Gils, 2008, Board of directors in family firms: a generational perspective, Small Business Economics 31(2), 163-180.

Beatty, A., Ke, B. and Petroni, K., 2002, Earnings management to avoid earnings declines across publicly and privately held banks, The Accounting Review 77(3), 547-570.

Beatty, R. P. (1989). Auditor reputation and the pricing of initial public offering. The Accounting Review, 64(4), 693-709.

Becker, C. L., DeFond, M. L., Jiambalvo, J., \& Subramanyam, K. R. (1998). The effect of audit quality on earnings management. Contemporary Accounting Research, 15(1), 1-24.

Ben-Amar, W., and P. André (2006). "Separation of Ownership from Control and Acquiring Firm Performance: The Case of Family Ownership in Canada," Journal of Business Finance \& Accounting, 33, 517-543.

Bozec, R. (2005). "Boards of Directors, Market Discipline and Firm Performance," Journal of Finance \& Accounting, 32, 1921-1960.

Brunninge, O., M. Nordqvist, and J. Wiklund (2007). "Corporate Governance and Strategic Change in SMEs: The Effects of Ownership , Board Composition and Top Management Teams," Small Business Economics, 29, 295-308.

Burgstahler, D., Hail, L. and Leuz, C., 2006, The importance of reporting incentives: earnings management in European private and public firms, The Accounting Review 81(5), 9831016.

Cano-Rodríquez, M. (2010). Big auditors, private firms and accounting conservatism: Spanish evidence. European Accounting Review, 19(1), 131-159.

Carey, P., Simnett, R., \& Tanewski, G. (2000). Voluntary demand for internal and external auditing by family businesses. Auditing: A Journal of Practice and Theory, 19, 37-51.

Chaney, P., Jeter, D., \& Shivakumar, L. (2004). Self-selection of auditors and audit pricing in private firms. The Accounting Review, 79(1), 51-72.

Chrisman, J. J., Chua, J. H., \& Litz, R. A. (2004). Comparing the agency costs of family and non-family firms: Conceptual issues and exploratory evidence. Entrepreneurship: Theory \& Practice, 28(4), 335-354.

Claessens, S., Djankov, S., Fan, J. \& Lang, L. (2002). Disentangling the incentive and entrenchment effects of large shareholdings. Journal of Finance, 57(6), 2741-71.

Craswell, A., Francis, J. and Taylor, S., 1995, Auditor brand name reputations and industry specialisations, Journal of Accounting and Economics 20, 297-332.

Dalton, D.R., C.M. Daily, A.E. Ellstrand, and J.L. Johnson (1998). "Meta-analytic Reviews of Board Composition, Leadership Structure, and Financial Performance," Strategic Management Journal, 19, 269-290.

DeAngelo, L. E. (1981). Auditor size and audit quality. Journal of Accounting and Economics, 3(3), 183-199. 
DeFond, M. L. (1992). The association between changes in client firm agency costs and auditor switching. Auditing: A Journal of Practice \& Theory, 11(1), 16-31.

Demsetz, H., and B. Villalonga (2001). "Ownership Structure and Corporate Performance," Journal of Corporate Finance, 7, 209-233.

Fama, E. (1980). "Agency Problems and the Theory of the Firm," Journal of Political Economy, 88, 288-307.

Fama, E.F., \& M.C. Jensen (1983). Separation of ownership and control. Journal of Law and Economics, 26, 301-325.

Fan, J. P. H., \& Wong, T. J. (2005). Do external auditors perform a corporate governance role in emerging markets? Evidence from East Asia. Journal of Accounting Research, 43(1), 35-72.

Fortin, S., \& Pittman, J. A. (2007). The role of auditor choice in debt pricing in private firms. Contemporary Accounting Research, 24(3), 859-896.

Francis, J. R., Maydew, E. L., \& Sparks, C. H. (1999). The role of Big 6 auditors in the credible reporting of accruals. Auditing: A Journal of Practice and Theory, 18(2), 17-34.

Francis, J. R. (2004). What do we know about audit quality? The British Accounting Review, $36,345-368$.

Francis, J. R., \& Krishnan, J. (1999). Accounting accruals and auditor reporting conservatism. Contemporary Accounting Research, 16(1), 135-165.

Gomez-Mejia, L., Haynes, K, Nunez-Nickel, M., Jacobson, K. and Moyano-Fuentes, J., 2007, Socioemotional wealth and business risks in family-controlled firms: evidence from Spanish olive mills, Administrative Science Quarterly 52, 106-137.

Gubitta, P., \& Gianecchini, M., 2002, Governance and flexibility in family-owned SMEs. Family Business Review 15, 277-297.

Hanlon, S., R. Kishida, and E. Poza, 2004, Does the family business interaction factor represent a resource or a cost?, Family Business Review 17(2), 99-118.

Harford, J., Mansi, S. and Maxwell, W., 2008, Corporate governance and firm cash holdings in the US, Journal of Financial Economics 87, 535-555.

Healy, P. (1985). The impact of bonus schemes on the selection of accounting principles. Journal of Accounting and Economics, 7, 85-107.

Jaffe, D., and S. Lane, 2004, Sustaining a family dynasty: key issues facing complex multigenerational business- and investment owning families, Family Business Review 17(1), 81-98.

James, H. (1999). Owner as manager, extended horizons and the family firm. International Journal of the Economics of Business, 6(1), 41-55.

Jensen, M.C., 1993, The modern industrial revolution, exit, and the failure of internal control systems, Journal of Finance 48(3), 831-880.

Jensen, M. and Meckling, W., 1976, Theory of the firm: managerial behaviour, agency costs and ownership structure, Journal of Financial Economics, 3, 305-60.

Johannisson, B. \& Huse, M., 2000, Recruiting outside board members in the small family business: an ideological challenge, Entrepreneurship, \& Regional Development 12, 353-378.

Kellermanns, F., and K. Eddleston, 2006, Corporate entrepreneurship in family firms: a family perspective, Entrepreneurship: Theory and Practice, 809-830. 
Knechel, R. W., Niemi, L., \& Sundgren, S. (2008). Determinants of auditor choice: Evidence from a small client market. International Journal of Auditing, 12(1), 65-88.

Lambrecht, J., and J. Lievens, 2008, Pruning the family tree: family business continuity and family harmony, Family Business Review 21(4), 295-313.

Lennox, C. S. (2005). Management ownership and audit firm size. Contemporary Accounting Research, 22(1), 205-227.

Lubatkin, M., Schulze, W., Ling, Y. \& Dino, R. (2005). The effects of parental altruism on the governance of family-managed firms. Journal of Organizational Behavior, 26, 313 30.

Mansi, S. A., Maxwell, W. F., \& Miller, D. P. (2004). Does auditor quality and tenure matter to investors? Evidence from the bond market. Journal of Accounting Research, 42(4), 755793.

Menon, K., \& Williams, D. D. (1991). Auditor credibility and initial public offerings. The Accounting Review, 66(2), 313-332.

Minichilli, A., Zattoni, A. and Zona, F., 2009, Making boards effective: an empirical examination of board task performance, British Journal of Management 20, 55-74.

Morck, R., \& Yeung, B. (2003). Agency problems in large family business groups. Entrepreneurship: Theory \& Practice, 27(4), 367-382.

Niskanen, M., Karjalainen, J. \& J. Niskanen. (2010). The Role of Auditing in Small, Private Family Firms: Is it about Quality and Credibility?, Family Business Review, 23(3), 230245.

Piot, C. (2001). Agency costs and audit quality: Evidence from France. The European Accounting Review, 10(3), 461-499.

Piot, C., 2005, Auditor reputation and model of governance: a comparison of France, Germany and Canada, International Journal of Auditing 9, 21-44.

Schulze, W., Lubatkin, M., Dino, R. \& Buchholtz, A. (2001). Agency relationships in family firms. Organization Science, 12(2), 99-116.

Schulze, W., Lubatkin, M. \& Dino, R. (2003). Exploring the agency consequences of ownership dispersion among the directors of private family firms. Academy of Management Journal, 46(2), 179-94.

Sirmon, D. \& Hitt, M. (2003). Managing resources: linking unique resources, management, and wealth creation in family firms. Entrepreneurship: Theory \& Practice, 27(4), 339358.

Sonfield, M., and R. Lussier, 2004, First-, second, and third-generation family firms: a comparison, Family Business Review 17(3), 189-202.

Sundgren, S. (1998). Auditor choices and auditor reporting practices: Evidence from Finnish small firms. The European Accounting Review, 7(3), 441-465.

Van Tendeloo, B., \& Vanstraelen, A. (2008). Earnings management and audit quality in Europe: evidence from the private client segment market. European Accounting Review, 17(3), 447-469.

Villalonga, B. \& Amit, R. (2006). How do family ownership, control and management affect firm value. Journal of Financial Economics, 80, 385-417.

Voordeckers, W., Van Gils, A. \& Van den Heuvel, J., 2007, Board composition in small and medium-sized family firms, Journal of Small Business Management 45(1), 137-156.

Watts, R. L., \& Zimmerman, J. L. (1986). Positive Accounting Theory. Englewood Cliffs, NJ: Prentice Hall. 
Westhead, P. \& Howorth, C. (2007). Types of private family firms: an exploratory conceptual and empirical analysis. Entrepreneurship \& Regional Development, 19, 405-431.

Westhead, P., 2003, Company performance and objectives reported by first and multigeneration family companies: a research note, Journal of Small Business and Enterprise Development 10, 93-105.

Westhead, P., C. Howorth, and M. Cowling, 2002, Ownership and management issues in first generation and multigeneration family firms, Entrepreneurship and Regional Development 14, 247-269.

Willenborg, M. (1999). Empirical analysis of the economic demand for auditing in the initial public offerings market. Journal of Accounting Research, 37(1), 225-238.

Zahra, S.A., and J.A. Pearce (1989). "Boards of Directors and Corporate Financial Performance: A Review and Integrative Model," Journal of Management, 15, 291-334. 
Table 1: Variable definitions

Variable Definition

Dependent variables

BIG_4 An indicator variable equal to 1 if an auditor represents one of the Big 4 audit firms, 0 otherwise

CERTIFIED An indicator variable equal to 1 in case of a certified KHT or HTM auditor, 0 otherwise

KHT An indicator variable equal to 1 in case of a certified KHT auditor, 0 otherwise

AUDITOR ( 1 = non-certified auditor or HTM auditor, 2 = non-Big 4 KHT auditor, 3 = Big4 KHT auditor)

Board and ownership variables

CEO_DUAL

NONFAM BM

OUTSIDE_BM

FAMILY

CEO_OS

B_SIZE

Control variables
AGE
LAW
SIZE
LEVERAGE
ROA
DISTRESS
QUICK
A_TURN
INV_REC
EXPORT
GROUP

An indicator variable equal to 1 if CEO is Chairman of the Board, 0 otherwise An indicator variable equal to 1 if at least one non-family board member, 0 otherwise. An indicator variable equal to 1 if at least one outside board member (i.e., other than family member, director, other personnel, or investor), 0 otherwise.

An indicator variable equal to 1 if family ownership is higher than 50 percent, 0 otherwise.

A percentage share of CEO's ownership

A natural logarithm of one plus the number of board members

A natural logarithm of one plus years since firm's incorporation

An indicator variable equal to 1 if a firm is legally obligated to have an audit by a HTM or KHT auditor (when at least two of the following criteria is met: employees > 10, turnover $>680000 €$, and total assets $>340000 €$ ), 0 otherwise

A natural logarithm of total assets

A ratio of total debt to total assets

A ratio of earnings before interest and taxes to total assets

An indicator variable equal to 1 if the book value of equity is negative, 0 otherwise

A ratio of current assets minus inventory to current liabilities

A ratio of sales to total assets

A ratio of inventory plus receivables to total assets

An indicator variable equal to 1 if a firm has foreign sales, 0 otherwise

An indicator variable equal to 1 if a firm is a member of group, 0 otherwise 
Table 2: Descriptive statistics

\begin{tabular}{|c|c|c|c|c|c|c|c|}
\hline \multicolumn{8}{|l|}{ Variables } \\
\hline Continuous: & & $N$ & Mean & Std. dev. & Median & Min & Max \\
\hline CEO_OS & & 1,637 & 46.801 & 33.884 & 50.000 & 0.000 & 100.000 \\
\hline B_SIZE & & 1,637 & 1.221 & 0.335 & 1.099 & 0.000 & 2.565 \\
\hline AGE & & 1,637 & 2.442 & 0.805 & 2.485 & 0.000 & 4.317 \\
\hline SIZE & & 1,637 & 5.735 & 1.214 & 5.628 & 1.988 & 10.119 \\
\hline LEVERAGE & & 1,637 & 0.204 & 0.339 & 0.112 & 0.000 & 8.826 \\
\hline ROA & & 1,637 & 0.154 & 0.231 & 0.145 & -1.990 & 1.228 \\
\hline QUICK & & 1,637 & 1.683 & 1.936 & 1.100 & 0.000 & 15.700 \\
\hline A_TURN & & 1,637 & 2.363 & 1.588 & 2.031 & 0.000 & 15.879 \\
\hline INV_REC & & 1,637 & 0.392 & 0.255 & 0.350 & 0.000 & 0.998 \\
\hline Discrete: & & $N$ & $\%$ & & & & \\
\hline BIG_4 & $=1$ & 220 & 13.44 & & & & \\
\hline CERTIFIED & $=1$ & 1,276 & 77.95 & & & & \\
\hline KHT & $=1$ & 516 & 31.52 & & & & \\
\hline AUDITOR & $=1$ & 1,082 & 66.10 & & & & \\
\hline & $=2$ & 335 & 20.46 & & & & \\
\hline & $=3$ & 220 & 13.44 & & & & \\
\hline CEO_DUAL & $=1$ & 798 & 48.75 & & & & \\
\hline OUTSIDE_BM & $=1$ & 252 & 15.39 & & & & \\
\hline FAMILY & $=1$ & 892 & 54.49 & & & & \\
\hline LAW & $=1$ & 624 & 38.12 & & & & \\
\hline DISTRESS & $=1$ & 65 & 3.97 & & & & \\
\hline EXPORT & $=1$ & 370 & 22.60 & & & & \\
\hline GROUP & $=1$ & 133 & 8.12 & & & & \\
\hline
\end{tabular}

This table presents descriptive statistics for the overall sample. CEO_OS is a percentage share of CEO's ownership. B_SIZE is a natural logarithm of one plus the number of board members. AGE is a natural logarithm of one plus years since firm's incorporation. SIZE is a natural logarithm of total assets. LEVERAGE is a ratio of total debt to total assets. ROA is a ratio of earnings before interest and taxes to total assets. QUICK is a ratio of current assets minus inventory to current liabilities. A_TURN is a ratio of sales to total assets. INV_REC is a ratio of inventory plus receivables to total assets. BIG_4 is an indicator variable equal to 1 if an auditor represents one of the Big 4 audit firms, 0 otherwise. CERTIFIED is an indicator variable equal to 1 in case of a certified KHT or HTM auditor, 0 otherwise. KHT is an indicator variable equal to 1 in case of a certified KHT auditor, 0 otherwise. AUDITOR is a categorical variable equal to 1 in case of a non-certified or HTM auditor; 2 in case of a non-Big 4 KHT auditor, and 3 in case of a Big 4 KHT auditor. CEO_DUAL is an indicator variable equal to 1 if CEO is Chairman of the board, 0 otherwise. OUTSIDE_BM is an indicator variable equal to 1 if at least one outside board member (i.e., other than family member, director, other personnel, or investor), 0 otherwise. FAMILY is an indicator variable equal to 1 if family ownership is higher than 50 percent, 0 otherwise. LAW is an indicator variable equal to 1 if a firm is legally obligated to have an audit by a certified HTM or KHT auditor, 0 otherwise. DISTRESS is an indicator variable equal to 1 if the book value of equity is negative, 0 otherwise. EXPORT is an indicator variable equal to 1 if a firm has foreign sales, 0 otherwise. GROUP is an indicator variable equal to 1 if a firm is a member of group, 0 otherwise. $N$ denotes the number of firm-year observations. Data cover years from 1999 to 2006. 


\begin{tabular}{|c|c|c|c|c|c|c|c|c|c|c|c|c|c|c|c|c|c|c|c|}
\hline & 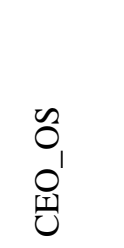 & $\begin{array}{l}\text { N } \\
\text { 茨 } \\
\infty^{\prime}\end{array}$ & 핀 & $\frac{1}{N}$ & 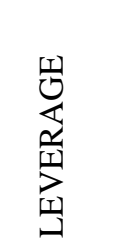 & $\begin{array}{l}\overleftrightarrow{\text { }} \\
\approx\end{array}$ & 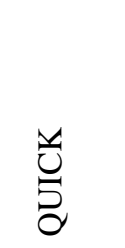 & 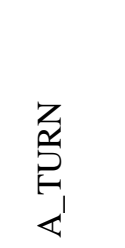 & $\begin{array}{l}\text { U } \\
\underline{I}_{1} \\
\mathbf{Z}_{\mathbf{Z}}\end{array}$ & $\frac{\nabla^{\prime}}{\bigcup_{0}^{\prime}}$ & 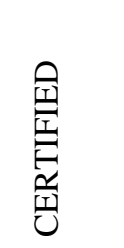 & $\stackrel{\vec{T}}{\underline{I}}$ & 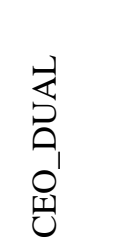 & 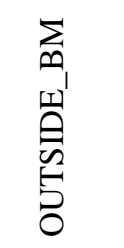 & 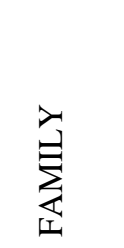 & 岕 & 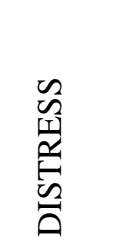 & 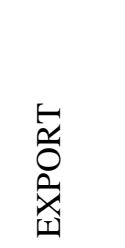 & 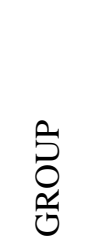 \\
\hline 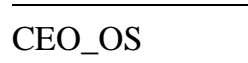 & & -0.360 & 0.000 & -0.184 & .021 & 0.129 & 0.005 & 0.066 & 70 & -0.132 & 0.084 & -0.210 & 0.377 & -0.210 & 0.108 & -0.154 & -0.031 & -0.111 & -0.234 \\
\hline B_SIZ & -0.347 & & 0.145 & 0.338 & 0.062 & -0.135 & -0.007 & -0.137 & .044 & 0.134 & & 0.168 & 0.379 & 0.390 & -0.195 & 0.282 & -0.077 & 0.197 & 0.184 \\
\hline AGE & 0.009 & 0.106 & & 0.248 & -0.021 & -0.046 & -0.037 & -0.163 & -0.016 & 0.079 & 0.163 & 0.055 & -0.102 & -0.026 & 0.122 & .180 & -0.046 & 0.074 & 0.082 \\
\hline SIZE & -0.222 & 0.354 & 0.240 & & 0.150 & -0.021 & -0.010 & -0.394 & 0.013 & 0.128 & 0.346 & 0.235 & -0.144 & 0.113 & 0.117 & 0.757 & -0.103 & 0.201 & 0.293 \\
\hline EVEI & -0.053 & 0.024 & -0.017 & 0.035 & & -0.386 & -0.375 & -0.291 & -0.163 & 0.040 & -0.017 & 0.002 & -0.038 & 0.038 & 0.055 & 0.028 & 0.127 & 0.180 & 0.059 \\
\hline $\mathrm{OA}$ & 0.153 & -0.115 & -0.012 & -0.006 & -0.358 & & 0.399 & 0.168 & -0.059 & -0.036 & -0.050 & -0.059 & 0.084 & -0.128 & 0.000 & 0.022 & -0.149 & -0.119 & -0.075 \\
\hline QUI & 0.009 & -0.063 & -0.012 & 0.005 & -0.104 & 0.170 & & -0.1 & -0.195 & 0.014 & 0.009 & 0 . & 0.008 & 0.032 & -0.109 & & -0.226 & $-\mathbf{0}$. & 0.003 \\
\hline RN & 0.069 & -0.133 & -0.158 & -0.340 & -0.164 & 0.061 & -0.222 & & 0.418 & -0.044 & -0.030 & -0.056 & 0.007 & -0.078 & -0.044 & -0.033 & 0.113 & -0.122 & -0.138 \\
\hline INV_REC & -0.063 & -0.070 & -0.009 & 0.024 & -0.152 & -0.059 & -0.213 & 0.338 & & -0.006 & 0.054 & 0.035 & -0.016 & -0.034 & 0.001 & 0.146 & 0.014 & 0.123 & 0.039 \\
\hline BIG_4 & -0.133 & 0.125 & 0.056 & 0.135 & 0.025 & -0.083 & 0.032 & -0.043 & -0.010 & & 0.210 & 0.430 & -0.083 & 0.174 & -0.097 & 0.100 & 0.039 & 0.104 & 0.073 \\
\hline ER & -0.095 & 0.135 & 0.154 & 0.339 & -0.007 & -0.062 & -0.015 & -0.023 & 0.049 & 0.210 & & 0.361 & -0.091 & 0.043 & 0.035 & 0.317 & -0.043 & 0.118 & 0.147 \\
\hline 1 & -0.212 & 0.156 & 0.043 & 0.237 & 0.024 & -0.130 & -0.019 & -0.0 & 0.035 & 0.430 & 61 & & -0.154 & 0.133 & -0.059 & 96 & 0.064 & 0.143 & 0.222 \\
\hline CEO & 0.385 & -0.378 & -0.100 & -0.164 & -0.050 & & & & -0.006 & -0.083 & -0.091 & -0.154 & & -0.209 & & & -0.054 & -0 & -0.098 \\
\hline DE_BN & -0.217 & 0.377 & -0.044 & 0.155 & 0.074 & -0.169 & -0.028 & -0.076 & -0.044 & 0.174 & 0.043 & 0.133 & -0.209 & & -0.273 & 0.056 & 0.061 & 0.109 & 0.189 \\
\hline FAMILY & 0.101 & -0.194 & 0.122 & 0.093 & -0.004 & 0.057 & -0.090 & -0.046 & 0.014 & -0.097 & 0.035 & -0.059 & 0.165 & -0.273 & & 0.078 & -0.109 & -0.043 & -0.056 \\
\hline LAW & 0.162 & 0.275 & 0.172 & 0.735 & -0.022 & 0.013 & -0.086 & 0.002 & 0.138 & 0.100 & 0.317 & 0.196 & -0.119 & 0.056 & 0.078 & & -0.050 & 0.159 & 0.218 \\
\hline DIST & -0.031 & -0.067 & -0.043 & -0.105 & 0.262 & -0.258 & -0 . & & & 0.039 & -0 . & & & 0.061 & -0.109 & -0.050 & & 0.017 & 0.008 \\
\hline EXPORT & 0.11 & 0.191 & 0.070 & 0.2 & 0.103 & -0.165 & -0.092 & & & 0.104 & & 0.143 & & 0.109 & & & 0.017 & & 0.112 \\
\hline GROUP & -0.243 & 0.204 & 0.092 & 0.314 & 0.020 & -0.118 & -0.049 & -0.082 & 0.034 & 0.073 & 0.147 & 0.222 & -0.098 & 0.189 & -0.056 & 0.218 & 0.008 & 0.112 & \\
\hline
\end{tabular}

This table presents Pearson (Spearman) correlations below (above) the diagonal. CEO_OS is a percentage share of CEO's ownership. B_SIZE is a natural logarithm of one plus the number of board members. AGE is a natural logarithm of one plus years since firm's incorporation. SIZE is a natural logarithm of total assets. LEVERAGE is a ratio of total debt to total assets. ROA is a ratio of earnings before interest and taxes to total assets. QUICK is a ratio of current assets minus inventory to current liabilities. A_TURN is a ratio of sales to total assets. INV_REC is a ratio of inventory plus receivables to total assets. BIG_4 is an indicator variable equal to 1 if an auditor represents one of the Big 4 audit firms, 0 otherwise. CERTIFIED is an indicator variable equal to 1 in case of a certified KHT or HTM auditor, 0 otherwise. KHT is an indicator variable equal to 1 in case of a certified KHT auditor, 0 otherwise. CEO_DUAL is an indicator variable equal to 1 if CEO is Chairman of the board, 0 otherwise. NONFAM BM is an indicator variable equal to 1 if at least one non-family board member, 0 otherwise. OUTSIDE BM is an indicator variable equal to 1 if at least one outside board member (i.e., other than family member, director, other personnel, or investor), 0 otherwise. FAMILY is an indicator variable equal to 1 if family ownership is higher than 50 percent, 0 otherwise. LAW is an indicator variable equal to 1 if a firm is legally obligated to have an audit by a certified HTM or KHT auditor, 0 otherwise. DISTRESS is an indicator variable equal to 1 if the book value of equity is negative, 0 otherwise. EXPORT is an indicator variable equal to 1 if a firm has foreign sales, 0 otherwise. GROUP is an indicator variable equal to 1 if a firm is a member of group, 0 otherwise. Data cover years from 1999 to 2006 and contains 1,637 observations. Correlations significant at the $1 \%$ confidence level are reported with bold characters. 
Table 4: Logistic regressions: Overall sample

\begin{tabular}{|c|c|c|c|c|}
\hline \multirow{2}{*}{$\begin{array}{l}\text { Dependent variable: BIG_4 } \\
\text { Variable }\end{array}$} & \multicolumn{2}{|c|}{ (1) } & \multicolumn{2}{|c|}{ (2) } \\
\hline & Coef. & $p$-value & Coef. & $p$-value \\
\hline Intercept & -3.5500 & 0.001 & -3.6476 & 0.000 \\
\hline FAMILY & -0.6802 & 0.029 & -0.4816 & 0.058 \\
\hline CEO_DUAL & -0.3326 & 0.351 & - & \\
\hline FAMILY x CEO_DUAL & 0.4148 & 0.386 & - & \\
\hline OUTSIDE_BM & - & & 0.6543 & 0.054 \\
\hline FAMILY x OUTSIDE_BM & - & & 0.5422 & 0.323 \\
\hline B_SIZE & 0.3894 & 0.367 & 0.1540 & 0.716 \\
\hline LAW & 0.0752 & 0.813 & 0.1347 & 0.672 \\
\hline AGE & 0.1108 & 0.446 & 0.1598 & 0.268 \\
\hline SIZE & 0.2355 & 0.103 & 0.2167 & 0.128 \\
\hline LEVERAGE & -0.0543 & 0.794 & -0.0506 & 0.805 \\
\hline ROA & -0.7588 & 0.047 & -0.6162 & 0.120 \\
\hline DISTRESS & 0.4173 & 0.323 & 0.4004 & 0.341 \\
\hline QUICK & 0.0684 & 0.247 & 0.0746 & 0.196 \\
\hline A_TURN & 0.0413 & 0.516 & 0.0475 & 0.460 \\
\hline INV_REC & -0.2037 & 0.697 & -0.1674 & 0.750 \\
\hline EXPORT & 0.3526 & 0.156 & 0.3733 & 0.130 \\
\hline GROUP & 0.0375 & 0.911 & -0.0818 & 0.805 \\
\hline Year controls & Yes & & Yes & \\
\hline$N$ & 1,637 & & 1,637 & \\
\hline Pseudo $R^{2}$ & 0.080 & & 0.091 & \\
\hline Correctly classified (\%) & 86.56 & & 86.87 & \\
\hline
\end{tabular}

B_SIZE is a natural logarithm of one plus the number of board members. AGE is a natural logarithm of one plus years since firm's incorporation. SIZE is a natural logarithm of total assets. LEVERAGE is a ratio of total debt to total assets. ROA is a ratio of earnings before interest and taxes to total assets. QUICK is a ratio of current assets minus inventory to current liabilities. A_TURN is a ratio of sales to total assets. INV_REC is a ratio of inventory plus receivables to total assets. BIG_4 is an indicator variable equal to 1 if an auditor represents one of the Big 4 audit firms, 0 otherwise. CEO_DUAL is an indicator variable equal to 1 if CEO is Chairman of the board, 0 otherwise. OUTSIDE_BM is an indicator variable equal to 1 if at least one outside board member (i.e., other than family member, director, other personnel, or investor), 0 otherwise. FAMILY is an indicator variable equal to 1 if family ownership is higher than 50 percent, 0 otherwise. LAW is an indicator variable equal to 1 if a firm is legally obligated to have an audit by a certified HTM or KHT auditor, 0 otherwise. DISTRESS is an indicator variable equal to 1 if the book value of equity is negative, 0 otherwise. EXPORT is an indicator variable equal to 1 if a firm has foreign sales, 0 otherwise. GROUP is an indicator variable equal to 1 if a firm is a member of group, 0 otherwise. $N$ denotes the number of firm-year observations per model. $p$-Values are based on standard errors clustered at the firm level. Coefficients significant at $10 \%$ level or better (based on two-tailed test) are reported with bold characters. Data cover years from 1999 to 2006. 
Table 5: Logistic regressions: Subsample of family firms

\begin{tabular}{|c|c|c|c|c|c|c|c|c|}
\hline Dependent variable: BIG_4 & ( & & $(2$ & & $(3$ & & ( & \\
\hline Sample & & $\begin{array}{l}\text { Fam } \\
\text { (FAN }\end{array}$ & $\begin{array}{l}\text { irms } \\
Y=1)\end{array}$ & & & $\begin{array}{l}\text { Larger } \\
\text { AMILY }\end{array}$ & $\begin{array}{l}\text { ly firms } \\
\text { LAW }=1\end{array}$ & \\
\hline Variable & Coef. & $p$-value & Coef. & $p$-value & Coef. & $p$-value & Coef. & $p$-value \\
\hline Intercept & $-\mathbf{3 . 8 2 9 7}$ & 0.033 & -3.7090 & 0.037 & -1.6243 & 0.586 & -2.0299 & 0.519 \\
\hline CEO_OS & -0.0149 & 0.165 & -0.0134 & 0.005 & -0.0281 & 0.068 & -0.0165 & 0.019 \\
\hline CEO_DUAL & 0.3206 & 0.526 & - & & 0.3039 & 0.679 & - & \\
\hline CEO_OS x CEO_DUAL & -0.0026 & 0.825 & - & & 0.0096 & 0.611 & - & \\
\hline OUTSIDE_BM & - & & 2.2488 & 0.001 & - & & 4.0845 & 0.000 \\
\hline CEO_OS x OUTSIDE_BM & - & & -0.0300 & 0.091 & - & & -0.0519 & 0.006 \\
\hline B_SIZE & -0.5465 & 0.369 & -0.8452 & 0.133 & -0.4255 & 0.583 & -1.6070 & 0.053 \\
\hline LAW & -0.0817 & 0.873 & 0.0526 & 0.922 & - & & - & \\
\hline AGE & 0.2955 & 0.218 & 0.4078 & 0.052 & 0.0584 & 0.875 & 0.5732 & 0.099 \\
\hline SIZE & 0.3847 & 0.122 & 0.3289 & 0.193 & 0.1926 & 0.587 & 0.1950 & 0.588 \\
\hline LEVERAGE & 0.4980 & 0.525 & 0.5403 & 0.500 & 1.1078 & 0.355 & 1.3787 & 0.300 \\
\hline ROA & -0.3936 & 0.715 & -0.3471 & 0.762 & -2.0822 & 0.237 & -1.3516 & 0.445 \\
\hline DISTRESS & 0.7093 & 0.269 & 0.5798 & 0.417 & -0.0981 & 0.930 & -1.2629 & 0.244 \\
\hline QUICK & 0.1021 & 0.125 & 0.1181 & 0.073 & 0.2995 & 0.023 & 0.3285 & 0.005 \\
\hline A_TURN & 0.0740 & 0.496 & 0.0826 & 0.454 & -0.0611 & 0.670 & -0.0063 & 0.969 \\
\hline INV_REC & -0.2156 & 0.786 & -0.0194 & 0.981 & -0.2467 & 0.800 & 0.0209 & 0.984 \\
\hline EXPORT & -0.3418 & 0.434 & -0.4552 & 0.271 & -0.3571 & 0.516 & -0.9093 & 0.127 \\
\hline GROUP & -0.7618 & 0.300 & -1.2048 & 0.154 & -0.5266 & 0.520 & -0.7024 & 0.378 \\
\hline Year controls & Yes & & Yes & & Yes & & Yes & \\
\hline$N$ & 892 & & 892 & & 371 & & 371 & \\
\hline Pseudo $R^{2}$ & 0.100 & & 0.128 & & 0.170 & & 0.261 & \\
\hline Correctly classified (\%) & 89.80 & & 89.69 & & 87.33 & & 88.41 & \\
\hline
\end{tabular}

CEO_OS is a percentage share of CEO's ownership. B_SIZE is a natural logarithm of one plus the number of board members. AGE is a natural logarithm of one plus years since firm's incorporation. SIZE is a natural logarithm of total assets. LEVERAGE is a ratio of total debt to total assets. ROA is a ratio of earnings before interest and taxes to total assets. QUICK is a ratio of current assets minus inventory to current liabilities. A_TURN is a ratio of sales to total assets. INV_REC is a ratio of inventory plus receivables to total assets. BIG_4 is an indicator variable equal to 1 if an auditor represents one of the Big 4 audit firms, 0 otherwise. CEO_DUAL is an indicator variable equal to 1 if CEO is Chairman of the board, 0 otherwise. OUTSIDE BM is an indicator variable equal to 1 if at least one outside board member (i.e., other than family member, director, other personnel, or investor), 0 otherwise. FAMILY is an indicator variable equal to 1 if family ownership is higher than 50 percent, 0 otherwise. LAW is an indicator variable equal to 1 if a firm is legally obligated to have an audit by a certified HTM or KHT auditor, 0 otherwise. DISTRESS is an indicator variable equal to 1 if the book value of equity is negative, 0 otherwise. EXPORT is an indicator variable equal to 1 if a firm has foreign sales, 0 otherwise. GROUP is an indicator variable equal to 1 if a firm is a member of group, 0 otherwise. $N$ denotes the number of firm-year observations per model. $p$-Values are based on standard errors clustered at the firm level. Coefficients significant at $10 \%$ level or better (based on two-tailed test) are reported with bold characters. 
Table 6: Multinomial logistic regressions: Subsample of family firms (FAMILY = 1)

\begin{tabular}{|c|c|c|c|c|c|c|c|c|}
\hline Dependent variable: AUDITOR & $(1$ & & & & $(3$ & & $(4$ & \\
\hline $\begin{array}{l}\text { Outcome: } \\
\text { (Base outcome = 1) }\end{array}$ & $\begin{array}{r}\text { 2: Non-Bi } \\
\text { audi }\end{array}$ & $\begin{array}{l}4 \mathrm{KHT} \\
\text { or }\end{array}$ & $\begin{array}{r}\text { 3: Big } \\
\text { auc }\end{array}$ & $\begin{array}{l}\text { KHT } \\
\text { or }\end{array}$ & $\begin{array}{r}2: \text { Non-B } \\
\text { aud }\end{array}$ & $\begin{array}{l}4 \mathrm{KHT} \\
\text { or }\end{array}$ & $\begin{array}{l}\text { 3: Big } \\
\text { audi }\end{array}$ & $\begin{array}{l}\text { KHT } \\
\text { or }\end{array}$ \\
\hline Variable & Coef. & $p$-value & Coef. & $p$-value & Coef. & $p$-value & Coef. & $p$-value \\
\hline Intercept & -3.6758 & $\mathbf{0 . 0 3 7}$ & -4.1491 & $\mathbf{0 . 0 3 4}$ & -3.3133 & 0.042 & -3.9677 & 0.040 \\
\hline CEO_OS & 0.0082 & 0.344 & -0.0130 & 0.274 & -0.0055 & 0.273 & -0.0148 & 0.005 \\
\hline CEO_DUAL & 0.5399 & 0.381 & 0.4528 & 0.427 & - & & - & \\
\hline CEO_OS x CEO_DUAL & -0.0195 & 0.074 & -0.0069 & 0.597 & - & & - & \\
\hline OUTSIDE_BM & - & & - & & -1.0059 & 0.253 & 1.9773 & 0.009 \\
\hline CEO_OS x OUTSIDE_BM & - & & - & & -0.0219 & 0.373 & -0.0280 & 0.134 \\
\hline B_SIZE & -0.5732 & 0.296 & -0.6754 & 0.290 & -0.1648 & 0.770 & -0.8871 & 0.130 \\
\hline LAW & 0.0436 & 0.934 & -0.0929 & 0.866 & 0.0281 & 0.958 & 0.0302 & 0.958 \\
\hline AGE & -0.1712 & 0.404 & 0.2412 & 0.352 & -0.2419 & 0.245 & 0.3472 & 0.130 \\
\hline SIZE & 0.5038 & 0.036 & 0.5133 & 0.068 & 0.4829 & 0.052 & 0.4540 & 0.111 \\
\hline LEVERAGE & -1.1395 & 0.174 & 0.2345 & 0.783 & -1.0926 & 0.180 & 0.3023 & 0.726 \\
\hline ROA & 0.4252 & 0.613 & -0.3153 & 0.785 & 0.4577 & 0.577 & -0.2365 & 0.843 \\
\hline DISTRESS & 1.4701 & 0.026 & 1.0725 & 0.141 & 1.3942 & 0.034 & 0.9251 & 0.244 \\
\hline QUICK & -0.0809 & 0.310 & 0.0897 & 0.192 & -0.0922 & 0.251 & 0.1025 & 0.133 \\
\hline A_TURN & 0.1371 & 0.281 & 0.1164 & 0.371 & 0.1116 & 0.370 & 0.1232 & 0.363 \\
\hline INV_REC & -0.7954 & 0.285 & -0.4306 & 0.618 & -0.8283 & 0.254 & -0.2434 & 0.787 \\
\hline EXPORT & 0.5966 & 0.143 & -0.1784 & 0.707 & 0.6184 & 0.133 & -0.2970 & 0.515 \\
\hline GROUP & 0.4921 & 0.458 & -0.5899 & 0.467 & 0.4189 & 0.549 & -1.0569 & 0.253 \\
\hline Year controls & Yes & & & & Yes & & & \\
\hline$N$ & 892 & & & & 892 & & & \\
\hline Pseudo $R^{2}$ & 0.097 & & & & 0.106 & & & \\
\hline
\end{tabular}

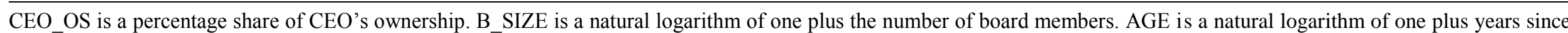

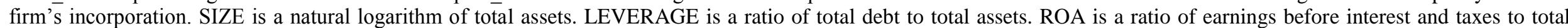

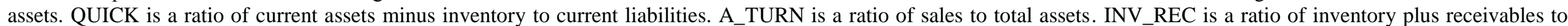

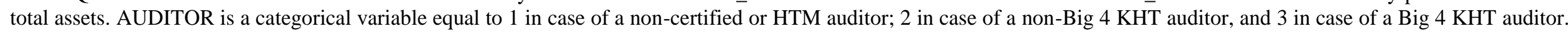

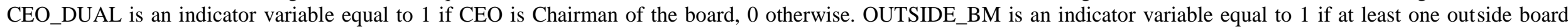

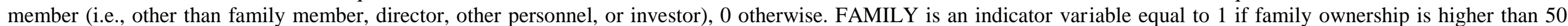

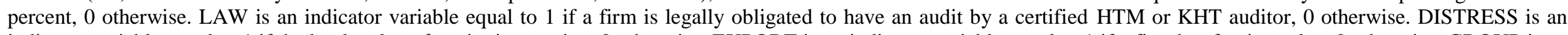

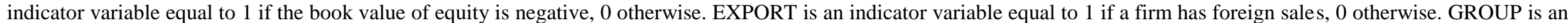

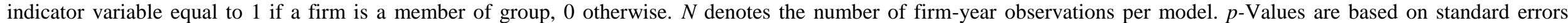
clustered at the firm level. Coefficients significant at $10 \%$ level or better (based on two-tailed test) are reported with bold characters. 
Table 7: Multinomial logistic regressions: Subsample of larger family firms (FAMILY = 1, LAW = 1)

\begin{tabular}{|c|c|c|c|c|c|c|c|c|}
\hline \multirow{3}{*}{$\begin{array}{l}\text { Dependent variable: AUDITOR } \\
\text { Outcome: } \\
\text { (Base outcome =1) } \\
\text { Variable }\end{array}$} & \multicolumn{2}{|c|}{ (1) } & \multicolumn{2}{|c|}{$(2)$} & \multicolumn{2}{|c|}{ (3) } & \multicolumn{2}{|c|}{ (4) } \\
\hline & \multicolumn{2}{|c|}{$\begin{array}{l}\text { 2: Non-Big } 4 \text { KHT } \\
\text { auditor }\end{array}$} & \multicolumn{2}{|c|}{$\begin{array}{l}\text { 3: Big } 4 \text { KHT } \\
\text { auditor }\end{array}$} & \multicolumn{2}{|c|}{$\begin{array}{l}\text { 2: Non-Big } 4 \text { KHT } \\
\text { auditor }\end{array}$} & \multicolumn{2}{|c|}{$\begin{array}{l}\text { 3: Big } 4 \text { KHT } \\
\text { auditor }\end{array}$} \\
\hline & Coef. & $p$-value & Coef. & $p$-value & Coef. & $p$-value & Coef. & $p$-value \\
\hline Intercept & -0.2962 & 0.928 & -1.1955 & 0.717 & 0.0409 & 0.989 & -1.4912 & 0.672 \\
\hline CEO_OS & 0.0018 & 0.876 & -0.0271 & 0.106 & -0.0051 & 0.520 & $-\mathbf{0 . 0 1 7 7}$ & 0.032 \\
\hline CEO_DUAL & 0.5293 & 0.528 & 0.4932 & 0.539 & - & & - & \\
\hline CEO_OS x CEO_DUAL & -0.0120 & 0.437 & 0.0056 & 0.784 & - & & - & \\
\hline OUTSIDE_BM & - & & - & & -0.1375 & 0.912 & 4.1112 & 0.000 \\
\hline CEO_OS x OUTSIDE_BM & - & & - & & -0.0137 & 0.575 & -0.0554 & 0.011 \\
\hline B_SIZ̄E & -0.7606 & 0.493 & -0.6166 & 0.469 & -0.4636 & 0.652 & -1.7170 & 0.057 \\
\hline $\mathrm{A} \overline{G E}$ & -0.3044 & 0.357 & -0.0462 & 0.908 & -0.3804 & 0.243 & 0.4534 & 0.246 \\
\hline SIZE & 0.0317 & 0.931 & 0.2121 & 0.604 & 0.0031 & 0.993 & 0.2097 & 0.614 \\
\hline LEVERAGE & 0.2078 & 0.865 & 1.1834 & 0.361 & 0.2104 & 0.865 & 1.4166 & 0.331 \\
\hline ROA & -1.1677 & 0.378 & -2.3923 & 0.197 & -1.1198 & 0.386 & -1.6686 & 0.374 \\
\hline DISTRESS & -12.436 & 0.000 & -0.5285 & 0.651 & $-\mathbf{1 2 . 2 0 7}$ & 0.000 & -1.7471 & 0.149 \\
\hline QUICK & 0.0456 & 0.751 & 0.3140 & 0.046 & 0.0384 & 0.788 & 0.3393 & 0.020 \\
\hline A_TURN & 0.1929 & 0.196 & 0.0030 & 0.986 & 0.1663 & 0.253 & 0.0489 & 0.802 \\
\hline INV_REC & -0.4912 & 0.668 & -0.3931 & 0.713 & -0.5395 & 0.629 & -0.1431 & 0.901 \\
\hline EXPORT & 0.6605 & 0.233 & -0.1335 & 0.816 & 0.6845 & 0.233 & -0.6866 & 0.281 \\
\hline GROUP & 0.5136 & 0.478 & -0.3535 & 0.688 & 0.5227 & 0.470 & -0.5247 & 0.540 \\
\hline Year controls & Yes & & & & Yes & & & \\
\hline$N$ & 371 & & & & 371 & & & \\
\hline Pseudo $R^{2}$ & 0.110 & & & & 0.148 & & & \\
\hline
\end{tabular}

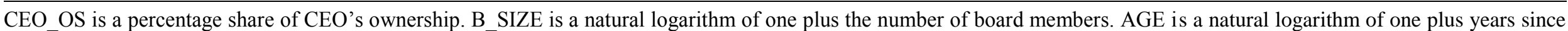

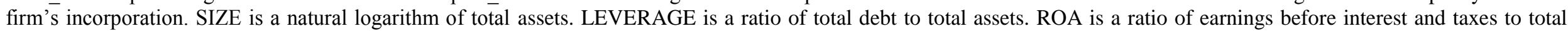

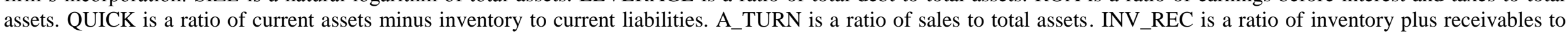

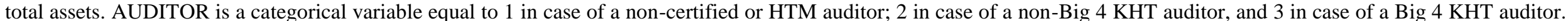

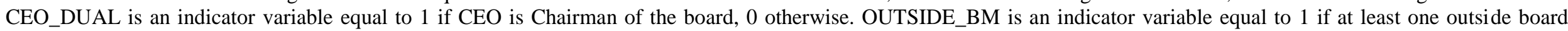

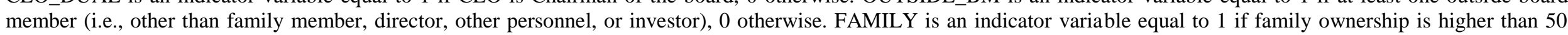
percent, 0 otherwise. LAW is an indicator variable equal to 1 if a firm is legally obligated to have an audit by a certified HTM or KHT auditor, 0 otherwise. DISTRESS is an

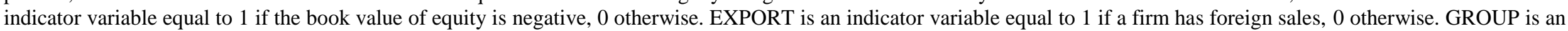

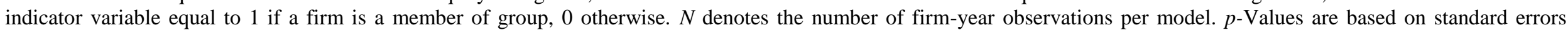
lustered at the firm level. Coefficients significant at $10 \%$ level or better (based on two-tailed test) are reported with bold characters. 